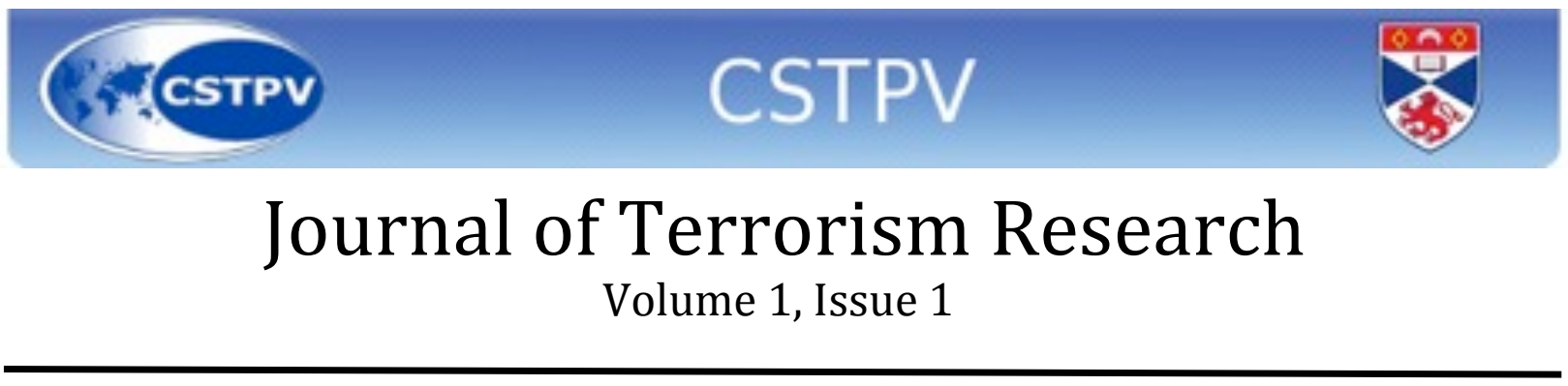

\title{
Case Studies in Exploiting Terrorist Group Divisions with Disinformation and Divisive/Black Propaganda
}

\section{by George Garner \\ Graduate Student of Terrorism and Nuclear Nonproliferation Monterey Institute of International Studies}

Counterterrorism operations should be exploiting the divisions and infighting of terrorist groups. The overall goal should be to make fewer mistakes than the jihadis, help increase inter-group and intra-group tension, and further their disconnection from the wider public. This paper argues that strategic psychological operations (PSYOP) that focus on exploiting rifts in leadership, differences in strategic planning, and ethnic, national and tribal differences within and among terrorist groups could be an integral part of overall counterterrorism efforts. Using three case studies, chosen because of the attention given to them in the international community and the illuminating group and leadership characteristics that can be found in many other jihadist organisations, the paper illustrates that PSYOP that expand on the existing framework could be very effective in countering the jihadist threat.

Field Manual (FM) 3-05.30 is the keystone publication for PSYOP principles of the United States military and a useful doctrine related to current psychological operations. It describes PSYOP as information for effect, used during peacetime and conflict, to inform and influence. Two of the specified roles embodied by these operations are influencing foreign populations and countering enemy propaganda, misinformation, disinformation, and opposing information. According to the field manual, PSYOP supports counterterrorism by integrating with other security operations to target the forces employing terrorism with the aim of placing the terrorist forces on the psychological defensive. To do so, forces may conduct operations seeking to counter the adverse effects of a terrorist act, decrease popular support for the terrorist cause, or publicise incentives to the local populace to provide information on terrorist groups. [1]

The utilisation of disinformation and divisive propaganda in PSYOP could be very effective in decreasing the threat posed by terrorist groups and their leadership. Disinformation involves the deliberate spread of false information in order to mislead or deceive a target audience. The goal of divisive propaganda is to separate groups. In instances where there may exist a number of loosely allied terrorist organisations, divisive propaganda can be utilised to create and further develop fractures between such entities. [2] Propaganda itself can be divided into three types, or forms, depending on whether the source and intention is known or unknown. White propaganda comes from an identified source and the information tends to be factually based. Black 


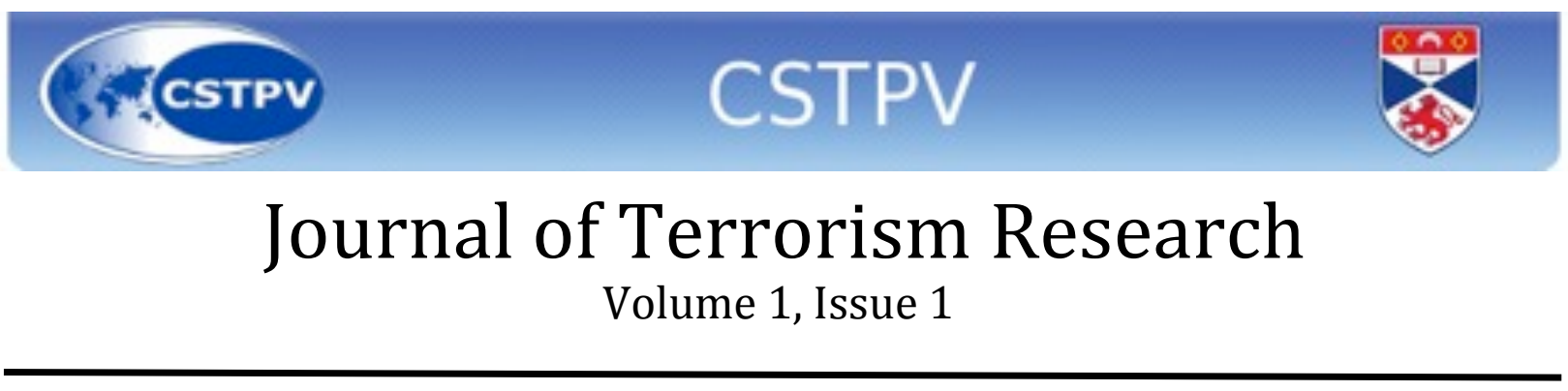

propaganda tends to imply secrecy; the information tends to be fabricated, and source identity deception is actively sought. Grey propaganda is placed somewhere in the middle; the aims and actual identity of the source may be known or unknown. Maintaining the use of black propaganda in possible PSYOP ensures that the information is presented by a source that will deflect prejudices the target audience may hold. This is especially important since anything the US does is closely scrutinised and blowback effect frequently occurs in counterterrorism operations. Strategies utilising disinformation, divisive propaganda, and black propaganda can weaken the inter-group, intra-group, and leader-rank-and-file cohesion. The tension, differences, and fighting within groups can be exploited to the extent that operations are hampered or terrorists redirect their focus from the enemy to one another.

In 1988, Ward Churchill, formerly of the University of Colorado, wrote an eccentric book with Jim Vander Wall on the FBI's Counterintelligence Program (COINTELPRO) against the Black Panther Party and American Indian Movement in the late 1960s and 1970s. One chapter of the book is devoted to the overall strategy of COINTELPRO, which lasted until 1971, when President Hoover suspended operations because of public disclosure. This particular chapter provides for a framework of unique opportunities in counterterrorism. COINTELPRO was designed to neutralise domestic political dissidents but can also be used to combat terrorist groups. One operation carried out by the FBI was the fabrication of correspondence between members of targeted groups, or between groups, designed to foster splits within or between organisations. Efforts were continued, and in some instances intensified, when it became apparent that the resulting tension was sufficient to cause physical violence among group members. [3] A second operation involved the infiltration of organisations with informers and agents provocateurs, the latter expressly for the purpose of carrying out illegal activities that could then be attributed to key organisational members and/or the organisation as a whole. Agents provocateurs were also assigned to disrupt the internal functioning of targeted groups and to assist in the spread of disinformation. [4] COINTELPRO also utilised snitch-jacketing. "Snitchjacketing, or bad-jacketing, refers to the practice of creating suspicion - through the spread of rumours or manufacture of evidence - that bona fide organisational members, usually

in key positions, are police/intelligence informers." [5] The purpose of this tactic was to isolate or eliminate organisational leadership and incite violence upon the jacketed individual. These three operations provide for a framework of possible counterterrorism tactics aimed at the very real, and very combustible, divisions within and among terrorist groups.

\section{Al Qaida Central}




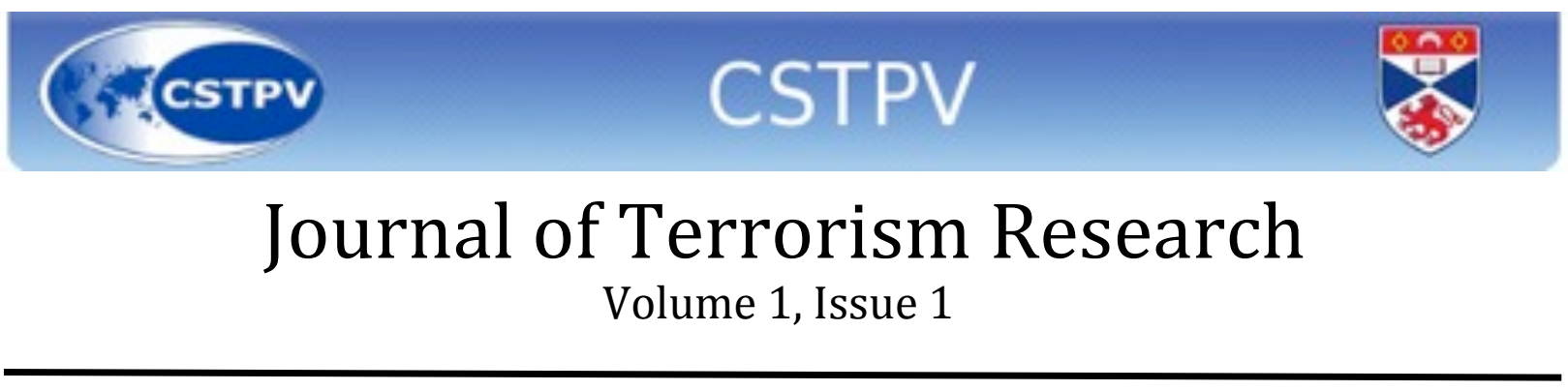

There were several members within the Al Qaida Majlis al-Shura, or governing council, who publicly criticised Osama Bin Ladin's leadership and his underestimation of the American response to the 9/11 attacks. The newspaper Asharq Al-Awsat obtained and published a document critical of Bin Ladin entitled "The Story of the Afghan Arabs: From the Entry into Afghanistan to the Final Exodus with the Taliban," written in the personal notebook of Abu alWalid al-Masri, a senior member and leading theoretician within Al Qaida, and veteran Afghan Arab. [6] Al-Masri was close to both Mullah Omar and Bin Ladin and his account illustrates the tenuous relationship between the two leaders. The document shows Bin Ladin in a highly negative light, managing Al Qaida like a tribal fiefdom, and frequently demonstrating disdain for Mullah Omar's advice. [7] In the lead-up to carrying out the 9/11 attack, Bin Ladin ignored the pleas of many within his inner circle, believing that the United States was weaker than imagined and unable to withstand significant attacks. Al-Masri was highly critical of Bin Ladin for stifling internal debate and hampering open and effective decision-making. According to his notebook, the final stages of Al Qaida's existence in Afghanistan represented:

A tragic example of an Islamic movement managed by a catastrophic leadership. Everyone knew that their leader was leading them to the abyss, and even leading the entire country to utter destruction, but they continued to bend to his will and take his orders with suicidal submission. [8]

This first-hand account sheds light on the tension and frustration aimed at Bin Ladin, emanating from both the Taliban leadership and Al Qaida's Majlis al-Shura.

Al-Masri also wrote of Bin Ladin's “extreme infatuation" or "crazy attraction" with the international media, a widely held view of Al Qaida's leader. Mullah Omar and other Taliban leaders often impressed on Bin Ladin the need to refrain from giving interviews to the media and involving the Taliban in unnecessary conflicts with the world community. [9] According to alMasri, Bin Ladin was fully prepared to sacrifice Afghanistan and Mullah Omar at the altar of his public relations campaign. Self-centered and manipulative, he was more concerned with his own image than with the security of his Taliban hosts. [10] Bin Ladin was becoming a liability and his conduct was costing the Taliban both Pakistani and official Arab support. In the end, Mullah Omar continued to brush off those around him, allowing Bin Ladin's actions to persist largely because he was grateful for the role played by Bin Ladin and his Arab mujahedeen during the Afghan War.

Tension within the ranks of Al Qaida also stemmed from the large contingent of Egyptians 


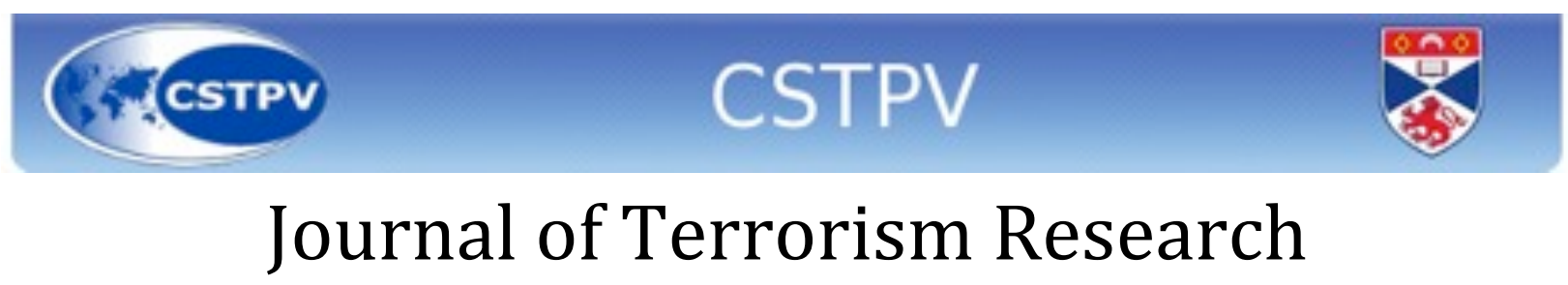

\section{Volume 1, Issue 1}

holding leadership roles in the organisation. After the 9/11 attacks, the international community overemphasised the role of Saudis and failed to see the vital role played by the lieutenants and strategic planners. According to former participants and Fawaz Gerges's interviews with jihadis, Ayman Zawahiri, Al Qaida's ideologue and second-in-command, planted around Bin Ladin trusted and competent Egyptian lieutenants from his former group, Egyptian Islamic Jihad, who subsequently became leading actors in Al Qaida. [11] The influence of Egyptian strategic planning would not have gone unnoticed within the lower echelons of the organisation. For example, some former jihadis were convinced that Zawahiri inducted Bin Ladin into suicide bombings, or martyrdom operations. Zawahiri had pioneered and legitimised these attacks against the near enemy. Since suicide bombings are in disagreement with classical Islamic political thought, which forbids suicide, either Bin Ladin was brainwashed or he underwent a revolutionary transformation thanks to the influence of Zawahiri. [12] The large presence of jihadists from Zawahiri's Islamic Jihad and the accompanying ideology created fault lines in Al Qaida between Egyptians and those from the Arabian Peninsula, in addition to the tension that marked Osama Bin Ladin's leadership.

The tenuous relationship between Mullah Omar and Bin Ladin, the frustration with Bin Ladin's leadership and obsession with the media, and the large contingent of Egyptian lieutenants were all potential opportunities for PSYOP against Al Qaida. The fabrication of correspondence between members of the Majlis al-Shura and Taliban leadership could have added to the calls for Bin Ladin's eviction from Afghanistan. Disinformation pointing out Bin Ladin's mixed record of participation with mujahedeen in the Afghan War could have furthered the gap felt between Arabs and Afghans. Tension stemming from the Egyptian contingent could have been capitalised upon by putting a label on those lieutenants who came from Islamic Jihad and distributing leaflets or documents comparing the strategic beliefs of Zawahiri to those of the overall group (also ensuring that they are written in Egyptian Arabic, and not modern standard or Iraqi dialect). In the early years of Al Qaida, the hegemony of Egyptians became such a sore point among other nationalities, particularly the Saudis, that Bin Ladin was forced to work hard to recruit young people from the Arabian Peninsula to establish an ethnic and nationality equilibrium within Al Qaida. [13] In regard to possible informers or agents provocateurs, statements emphasising Bin Ladin's disdain for Mullah Omar and lack of responsibility felt towards the Taliban could have been circulated within the ranks of both groups. In addition, fabricated media interviews and statements could have furthered the views of the sheikh as a publicity hound. In regards to snitch-jacketing, there was a very real possibility of painting Bin Ladin as an American intelligence agent. This is not far-fetched considering that, after 9/11 an anti-Bin Ladin faction among the Taliban, who were opposed to his presence in Afghanistan, actually advanced a 


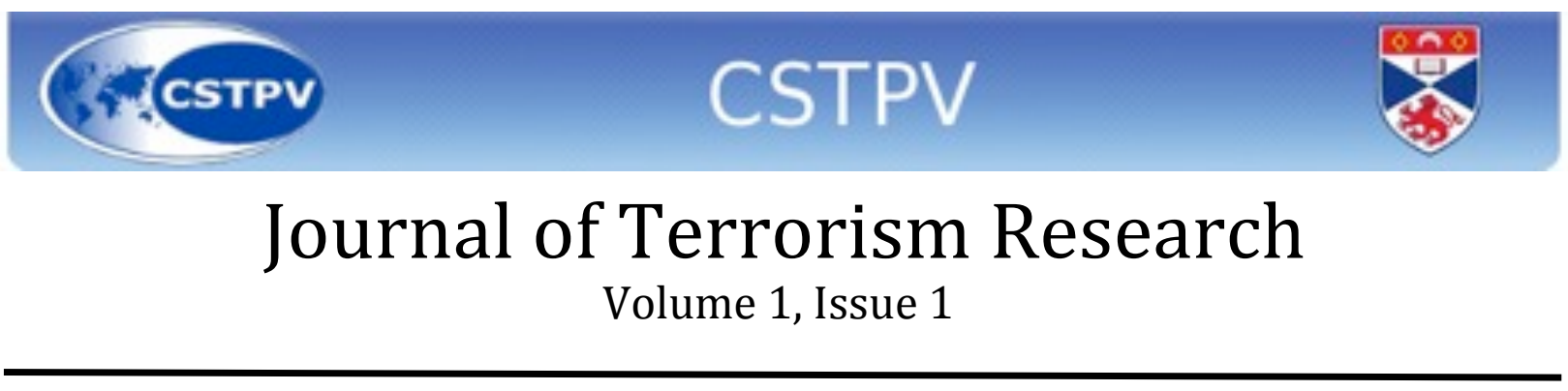

conspiratorial theory and claimed that he had been sent by Americans as a ploy to destroy the Taliban emirate. [14]

\section{Al Qaida in Mesopotamia}

In 2004, Abu Musab al-Zarqawi formally pledged bayat to Osama bin Ladin, and his jihadist group, Jamaat al-Tawhid wa al-Jihad in Iraq, was renamed Al Qaida in Mesopotamia (also known as Al Qaida in Iraq). However, according to Oraib Rantawi, the director of the Al-Quds Centre for Political Studies in Amman:

From the beginning, Zarqawi wanted to be independent. Yes, he gained stature through this alliance, but he only swore bayat after all this time because of growing pressure from Iraqis who were members of Al Qaida. [15]

Doctrinally, Zarqawi saw eye-to-eye with Al Qaida but he "was not fully pleased with the network's modus operandi. He criticised Al Qaida for not being fierce enough to deal more violent and more painful strikes to the enemy."[16] Initially, Bin Ladin himself was reluctant to incorporate al-Tawhid wa al-Jihad because of Zarqawi's excessive sectarianism and reckless killing of civilians. Rantawi suggests that "his suicide bombings of the hotels in Amman (in which some sixty civilians died, many of them while attending a wedding celebration) were a huge tactical mistake. My understanding is that Bin Ladin was furious about it." [17] The sheikh was also reportedly against the sectarian violence between Shiites and Sunnis, since it could cause distractions from the main confrontation with the US.

Personal testaments by Abu Mohammad al-Maqdisi, Zarqawi's former spiritual mentor, and other close associates painted Zarqawi as an ultra militant who was even more hardline than the hardliners within Al Qaida. He was more interested in action than in preaching and indoctrination and had an impulsiveness and recklessness that disturbed his cohorts. [18] A1Maqdisi, currently under house arrest in Jordan, also became one of the most vocal critics of Al Qaida in Mesopotamia's indiscriminate killing of civilians and fellow Muslims. In several interviews with Arabic language newspapers and Al-Jazeera, al-Maqdisi said that violence that does not differentiate between women and children, civilians, soldiers and American troops is wrong.

The kidnapping and murder of relief workers and neutral journalists have distorted the image of jihad. They make the mujahedeen look like murderers who spill blood blindly. [19] 


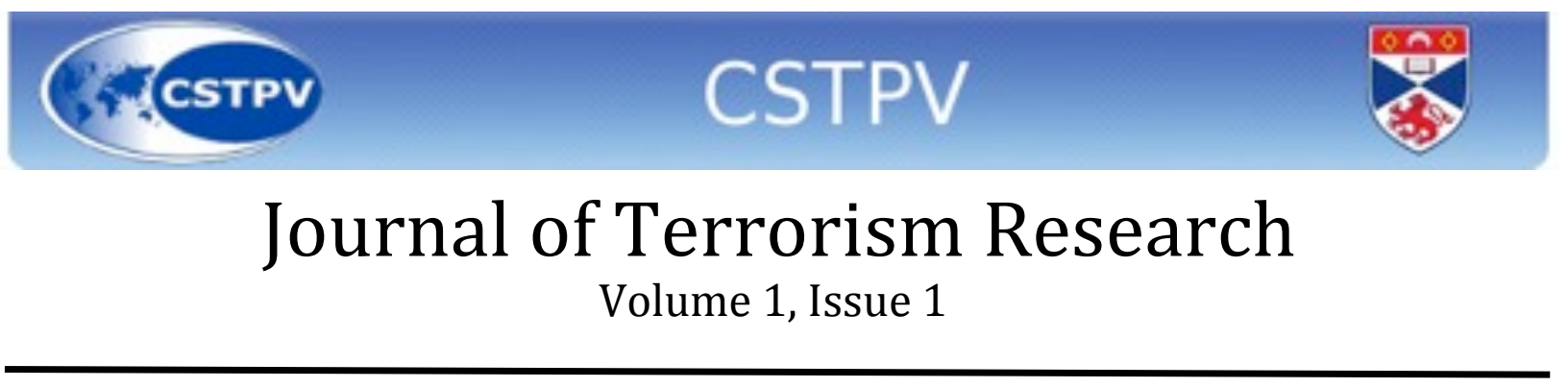

In addition, Sheikh Mohamed Sayed Tantawi, the grand imam of al-Azhar mosque in Cairo up until his death this March, called on the international community to put an end to terrorism in Iraq and to punish Zarqawi and his men for killing civilians. In two other separate statements, imprisoned leaders of the Egyptian Islamic Group and Islamic al-Jihad, the two largest jihadist organisations in the world, also criticised Zarqawi. [20]

The press reported skirmishes between Al Qaida and domestic Iraqi fighters, partly due to the indiscriminate suicide bombings of civilians, and perhaps also due to the Jordanian and Syrian backgrounds of the rank-and-file and higher echelons of Al Qaida in Mesopotamia. In addition to the lieutenants Zarqawi brought with him from connections forged in Jordanian jail, he focused much of the recruitment effort in Syria, Jordan and Palestine. The Syrian contingent of Al Qaida in Mesopotamia became just as vital as the Jordanian one, especially considering the rapid turnover rate of Zarqawi's lieutenants. [21] The group declared on the Internet in January of 2006 that it had joined Iraqi insurgent factions to form the Mujahedeen Shura Council, a move seen as part of a response to pressure from the public and indigenous fighters that Zarqawi tone down indiscriminate killing of Iraqis. He was alienating the very constituency that he claimed to be defending against foreign occupiers. Then, in early April, the 'Iraqi resistance's high command' announced that it had stripped al-Zarqawi of his political role and relegated him to military operations. [22] Even more remarkable, Zawahiri dispatched a 6,000-word letter to Zarqawi, chiding him that he risked alienating Arabs. "In the absence of this popular support," Zawahiri wrote, "the jihadist movement would be crushed in the shadows." [23] In addition to the tension aimed at Zarqawi's leadership originating from within the group, fault lines were created between Iraqis and foreigners, Shiites and Sunnis.

Zarqawi's interest in independence from greater Al Qaida, his indiscriminate killing of fellow Muslims, and the divisions between Iraqis and foreigners, Sunni and Shiite, all posed opportunities for PSYOP against Al Qaida in Mesopotamia. The distribution of fabricated correspondence between Bin Ladin (or more likely Zawahiri) and Zarqawi, focusing on Bin Ladin and his lieutenants' distrust and frustration with Zarqawi, as well as his supersize ego, could have intensified the division between Al Qaida central and the franchise group, as well as Zarqawi's isolation. Disinformation and agents provocateurs could have added to the number of sectarian and indiscriminate killings to Zarqawi's name, furthering the view of him and his followers as ruthless, sectarian foreigners. In regards to snitch-jacketing, perhaps Zarqawi could have also been painted as a pawn of the US. Interestingly enough, the case of Al Qaida in Mesopotamia is an example of one of the more recent attempts to incorporate PSYOP in counterterrorism, but the approach was all wrong. According to an April 2006 Washington Post 


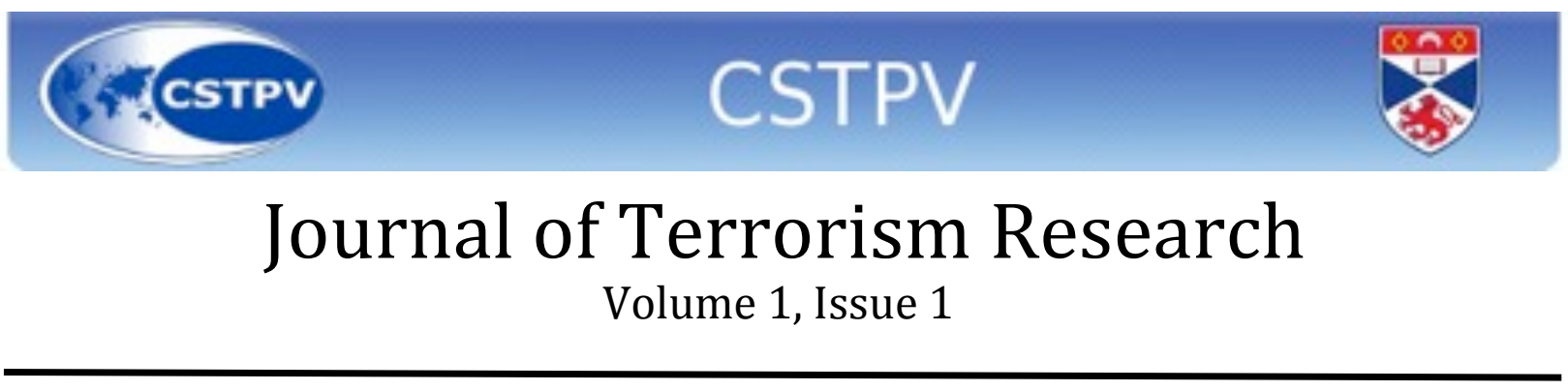

article, the US. military was conducting a propaganda campaign at the time to magnify the role played by Zarqawi in the Iraqi insurgency. Documents stated that the US campaign aimed to turn Iraqis against Abu Musab al-Zarqawi, a Jordanian, by playing on their perceived dislike of foreigners. [24] US military leaders were using leaflets, radio and television broadcasts and Internet postings as part of the PSYOP. A month after the Washington Post report, the military appeared to attempt to reverse field and portray al-Zarqawi as an incompetent who could not even handle a gun.[25] Fou'ad Hussein, Zarqawi's biographer, claimed that by exaggerating Zarqawi's military strength and blaming most attacks in Iraq on foreign terrorists led by Zarqawi, the US turned him into a "hero and symbol" of resistance in the eyes of the Arabs: "Every Arab and Muslim who wished to go to Iraq for jihad wanted to join al-Zarqawi and fight under his leadership." [26\} What the PSYOP should have done was blame only the sectarian attacks on Zarqawi, while creating suspicion, through the spread or rumors or false evidence, that he was in fact working for US intelligence, ensuring the need for more troops and a continued presence in the country.

\section{Tehrik-e-Taliban Pakistan}

The Pakistani Taliban movement emerged as the younger brother of the Afghan Taliban, who occasionally must be reigned in for attacking civilian targets, but who shares broader objectives. It became a network of numerous factions, with the original Afghan Taliban and Baitullah Mehsud's faction at the base. Recruits and funding are shared between the movements, and the only real division between the two is one of labour. The Pakistani Taliban were first forced to come together by Afghan Taliban emir Mullah Omar after broader differences fostered violent competition between the factions. On December 12, 2007, 40 senior Pakistani Taliban leaders, commanding some 50,000 men, gathered in Peshawar under the banner of Tehrik-e-Taliban Pakistan (TTP). Until then, many of them had carved out their own turfs in the Federally Administered Tribal Areas (FATA), often working at cross-purposes in their resistance to both American and Pakistani forces. [27]

The initial council that met in Peshawar elected Baitullah Mehsud as the first chief of the TTP, though not without objections from various leaders vying for power, including Wali-ur Rehman. Baitullah Mehsud's TTP was blamed for some of the most high-profile attacks in Pakistan for years, including the assassination of former Prime Minister Benazir Bhutto and a suicide attack on the Marriott Hotel in Islamabad. The hotel attack was sanctioned and applauded by Al Qaida, and in turn brought the TTP further into the limelight and under the Taliban movement.

In early August of 2009, a CIA drone attack in South Waziristan killed Baitullah Mehsud. In the 


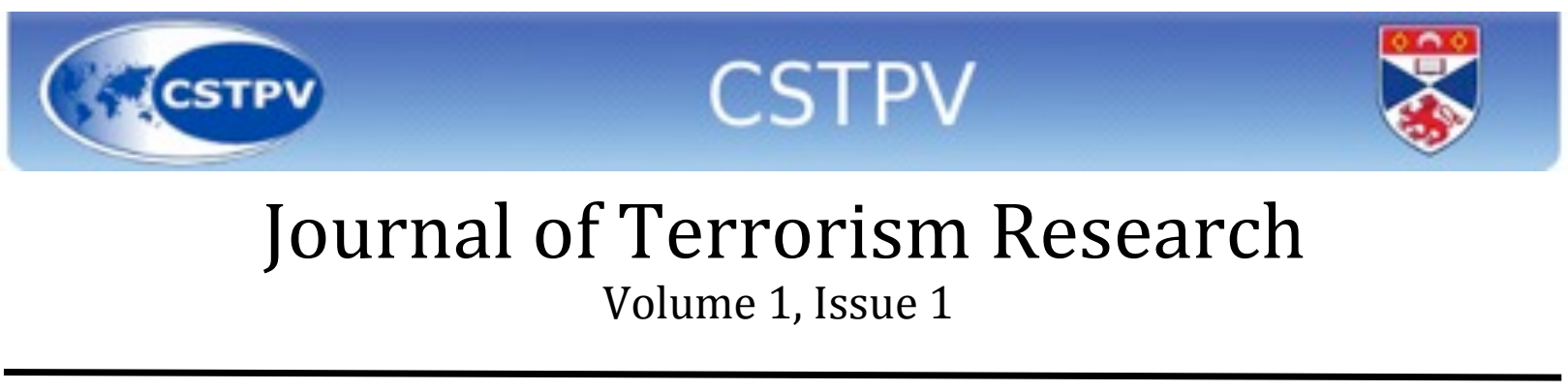

wake of his death, a power struggle marked by vicious infighting took place. At a meeting of surviving commanders and potential successors in August of 2009, at Sara Rogha in South Waziristan, a gunfight ensued. The Pakistani interior minister, Rehman Malik, confirmed reports of the shootout at the meeting and mentioned that someone had been killed. "The infighting was between Wali-ur Rehman and Hakimullah Mehsud," proclaimed Malik. [28] Reports speculated that during an argument over succession at the tribal jirga, shots were fired across a table, a brawl erupted and Hakimullah Mehsud was killed and Rehman wounded. A resident of the area who spoke by telephone to reporters after the incident said foreign militants favoured Mr. Rehman, while local militants favored Hakimullah Mehsud, Baitullah's protégé and cousin, to be their new leader. [29] To add to the confusion, another commander, Faqir Mohammad, proclaimed that he had taken over as leader of the group and had been endorsed by Hakimullah. Soon afterwards, Mohammad told the Agence France-Presse:

I am the most senior leader of the TTP after Baitullah, and the sacrifices I rendered for it are no less. However, due to some unavoidable reasons, I am stepping down. There is no factionalism within the TTP now. [30]

Clashes that followed between pro-Mehsud and anti-Mehsud factions reportedly killed more than a hundred militants in the tribal areas. According to Ismail Khan, Peshawar bureau chief of Dawn newspaper, a fierce rivalry exists within the pro-Mehsud elements. "There are problems within the leadership that are not all resolved," he claims. [31]

The death of Baitullah Mehsud and the entrance of Hakimullah Mehsud shed light on the tension between the various factions that make up Tehrik-e-Taliban. Hakimullah Mehsud, who Pakistani intelligence officials now believe survived a CIA drone aircraft strike in January, is thought no longer to run the Pakistani Taliban. Pakistani intelligence officials now say that Hakimullah's credibility within the TTP has receded and Taliban commanders like Wali-ur-Rehman are once again positioning for leadership.

The power struggle marked by vicious infighting that seems to take place every time a leader of Tehrik-e-Taliban Pakistan is killed provides for an ample opportunity in PSYOP. The factionalism inherent in a group that first came together from some 40 leaders vying for territory is one potential target. Fabricated correspondence between these various commanders, or their replacements, could capitalise on the power struggles. If foreign militants favour Wali-urRehman, and local militants favour Hakimullah Mehsud, this is a division that can be exploited. 


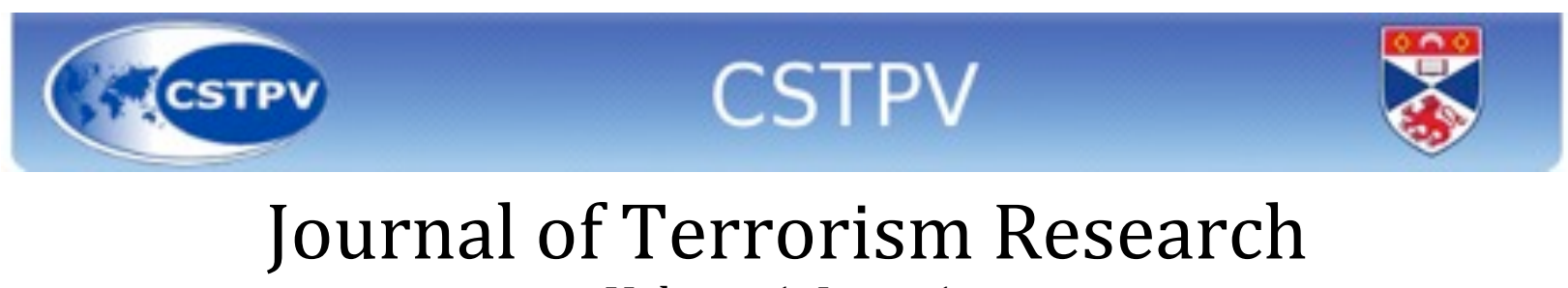

\section{Volume 1, Issue 1}

Even without any PSYOP or help from the outside, the meeting of successors following Baitullah Mehsud's death last year turned into a brawl and shootout. The actions of commanders like Faqir Mohammad, who claimed leadership to Agence France-Presse shortly after, can also serve as an example. There must have been confusion within the rank-and-file when more than one commander claimed control; why not make it a dozen? In addition, agents provocateurs could have spread disinformation and committed violence on behalf of various commanders, further spinning the situation out of control. The changeover in leadership of groups like the Pakistani Taliban is marked by complete chaos. A good idea for counterterrorism operations in this respect is simply to add fuel to the fire.

\section{Opportunities in Counterterrorism}

The use of divisive propaganda in PSYOP could include the fabrication and distribution of publications (leaflets, etc.) or correspondence 'on behalf of' targeted organisations or individuals designed to misrepresent their positions, goals, or objectives in such a way as to publicly discredit them or foster intra/inter-group tensions. [32] When formulating the divisive (and subsequently black) propaganda, it is important that the supposed source be a credible one. The criticisms of Bin Ladin likely resonated with jihadists because they came from within Al Qaida's highest circles and drew on close experiences of the Taliban movement and the Bin Ladin network. [33] Considering al-Maqdisi is, or at least was, the mufti of the Salafi-jihadi movement, his public criticism of Zarqawi reportedly caused considerable tension among Al Qaida. The use of informers or agents provocateurs in PSYOP could include the attribution of negative actions to key members and leaders, as well as the spread of disinformation in order to disrupt internal activity. The use of snitch-jacketing in PSYOP could be implemented through the spread of rumors or fabricated evidence that key members are intelligence informers or pawns of foreign governments, thus isolating or leading to the elimination of the leadership. At the juncture in which the snitch-jacketing takes hold within an organisation, it begins to unravel, and eat itself alive. The members could become increasingly factionalised and isolated from one another. In cases where extreme danger is involved, members may also begin to kill one another as a desperate means to perceived self-preservation. [34]

PSYOP are not without their own challenges and practical issues. Establishing credibility in planting agents provocateurs because of a lack of suitable candidates with the correct ethnic, linguistic, and religious make-up is one particular problem. However, this is the same difficulty, to which there is no real alternative, that plagues intelligence agencies in recruiting credible sources within terrorist groups. The high rates of illiteracy in relevant areas is another practical issue, especially in the TTP areas of operation in Pakistan, which makes the distribution of literature-based PSYOP potentially problematic. This makes the infiltration of organisations with 


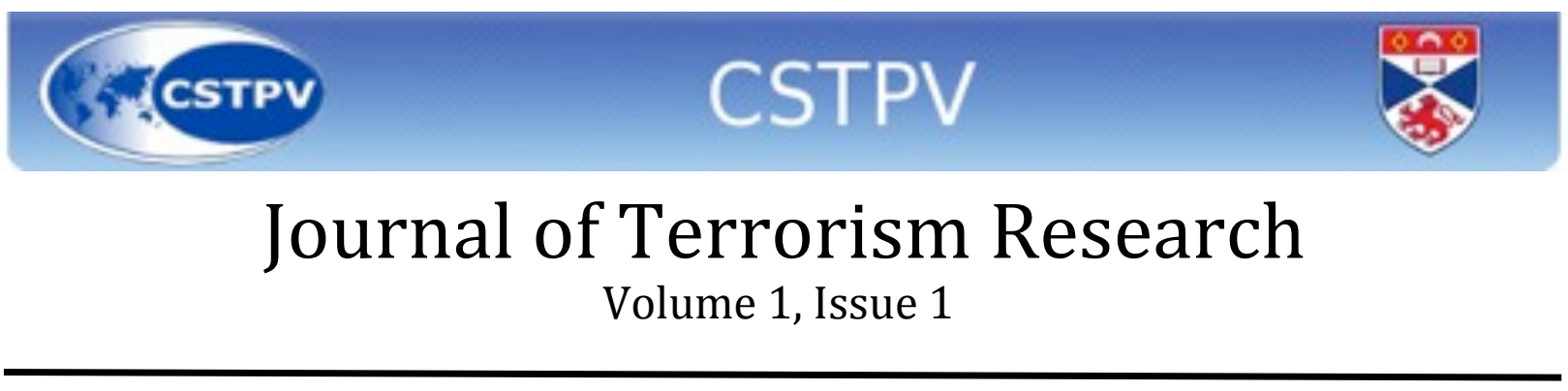

informers, the spread of rumours, and the manufacture of evidence even more important.

Domestic law and policy, along with international conventions, regulations and treaties, delineate the boundaries of PSYOP activity in counterterrorism. It is indeed important to recognise the ethical issues of PSYOP,in particular when agents provocateurs are encouraged to carry out acts of violence. This paper's aim is simply to point out the potential for PSYOP in recent conflicts, including the GWOT, and not to argue the moral justification of its use.

Fawaz Gerges summed up the potential for exploiting terrorist group division in his book The Far Enemy:

The sociology of jihadis does not differ much from that of their nationalist counterparts; jihadis tend to be just as prone to political positioning, calculation, and power struggle. The warriors of God also unconsciously internalised nationalism and sometimes acted as members of separate tribes, although they would be shocked to be told so because they spent a lifetime portraying themselves as the vanguards of the Ummah. [35]

Terrorist group leaders fight each other for power, lose public support for killing their own, display symptoms of paranoia and identify themselves with nations, ethnicities and tribes. Since mistakes made in counterterrorism operations increase the widespread support for jihadist groups, the best way forward could simply be to help terrorists make more with PSYOP.

George Garner graduated from Tulane University with a B.S. in Psychology. He is currently pursuing an M.A. in Nonproliferation and Terrorism Studies at the Monterey Institute of International Studies in California. His studies focus on the Middle East and South Asia.

This article was originally published on the 22/07/10 at http://www.st-andrews.ac.uk/ cstpv/jtr/ vlil/jtr1_1 garner casestudies.html

\section{Bibliography}

Field Manual - Psychological Operations. http://www.fas.org/irp/doddir/army/fm3-05-30.pdf

"The Afghan-Arabs Part One." Asharq Alawsat, June 29, 2005. http://www.asharqe.com/ news.asp? section=3\&id=627 Ahmed, Issam. "Pakistani Taliban Name Another New Chief." The Christian Science Monitor, 


\section{Journal of Terrorism Research}

\section{Volume 1, Issue 1}

August 23, 2009. Churchill, Ward and Jim Vander Wall. Agents of Repression. Cambridge: South End Press, 1988.

Díaz, G. and K. Moravej. "Covert Action and its Necessity in 21st Century Counterterrorism." UNISCI Discussion Papers no. 11 (May 1, 2006): 99-114

Gerges, Fawaz A. The Far Enemy: Why Jihad Went Global. Cambridge: Cambridge University Press, 2005.

Gerges, Fawaz A. "Buried in Amman's Rubble: Zarqawi's Support." The Washington Post, December 4, 2005.

Hussien, Fou'ad. "Al-Zarqawi...: The Second Generation of Al Qaeda - Abu al-Montasseri's Testament.” Al Quds al-Arabi, Part 2, May 14-15, 2005.

Hussein, Fou'ad. “Al-Zarqawi...: The Second Generation of Al Qaeda.” Al-Quds al-Arabi, Part 3, May 16, 2005.

Khan, Ismail and Sabrina Tavernise. "Feuding Kills a Top Militant, Pakistan Says." New York Times, Aug 9, 2009.

Mir, Amir. "Chevalier of the Undead." Outlook India, November 2, 2009.

Ricks, Thomas E. "Military Plays Up Role of Zarqawi; Jordanian Painted As Foreign Threat To Iraq's Stability." The Washington Post, April 10, 2006.

Weaver, Mary Anne. "Inventing Al-Zarqawi." The Atlantic Monthly, July 1, 2006, $87-88,9096,98,100$.

\section{Notes}

[1] Field Manual - Psychological Operations, http://www.fas.org/irp/doddir/army/fm3-05-30.pdf

[2] G. Diaz \& K. Moravej, 'Covert Action and its Necessity in 21 ' Century Counter-terrorism,' UNISCI Discussion Papers, No. 11 (May 1, 2006): 99-114

[3] W. Churchill \& J. Vander Wall, Agents of Repression, (Cambridge: South End Press, 1988), 41

[4] Ibid, 47

[5] Ibid, 49 


\section{Journal of Terrorism Research}

\section{Volume 1, Issue 1}

[6] 'The Afghan-Arabs Part One,' Asharq Alawsat June 29, 2005. http://www.asharge.comnews.asp?section=3\&id=627

[7] F. A. Gerges, The Far Enemy: Why Jihad Went Global (Cambridge: Cambridge University Press, 2005), 192

[8] Op. Cit. 'The Afghan-Arabs Part One'

[9] F. A. Gerges, Op. Cit., 193

[10] Ibid, 194

[11] Ibid, 139

[12] Ibid, 142

[13] Ibid, 140

[14] Ibid, 194

[15] M. A. Weaver, 'Inventing Al-Zarqawi,' The Atlantic Monthly, July 1, 2006, 87-88, 90-96, 98, 100.

[16] F. Hussein, 'Al-Zarqawi...: The Second Generation of Al Qaeda - Abu al-Montasseri’s Testament,' Al Quds al-Arabi, Part 2, May 14-15, 2005

[17] Ibid

[18] F. A. Gerges, Op. Cit., 254

[19] Ibid, 256

[20] F. A. Gerges, 'Buried in Amman's Rubble: Zarqawi’s Support,' The Washington Post December 4, 2005

[21] F. A. Gerges, The Far Enemy, 253

[22] M. A. Weaver, Op. Cit., 87-88, 90-96, 98, 100

[23] F. A. Gerges, Op. Cit., 254

[24] T. E. Ricks, 'Military Plays Up Role of Zarqawi; Jordanian Painted As Foreign Threat To Iraq's Stability,' The Washington Post April 10, 2006

[25] M. A. Weaver, Op. Cit., 87-88, 90-96, 98, 100

[26] F. Hussein. "Al-Zarqawi...: The Second Generation of Al Qaeda.” Al-Quds al-Arabi, Part 3, May 16, 2005.

[27] A. Mir, 'Chevalier of the Undead,' Outlook India, November 2, 2009

[28] I. Khan \& S. Tavernise, 'Feuding Kills a Top Militant, Pakistan Says,' New York Times, August 9, 2009

[29] Ibid

[30] I. Ahmed, 'Pakistan Taliban Name Another New Chief,' The Christian Science Monitor, August 23, 2009

[31] Ibid

[32] W. Churchill \& J. Vander Wall, Op. Cit., 42

[33] F. A. Gerges, Op. Cit., 198

[34] W. Churchill \& J. Vander Wall, Op. Cit., 212

[35] F. A. Gerges, Op. Cit., 141 